\title{
Effects of Transformational Leadership on Student Educational Satisfaction and Student Stress
}

\author{
Amarjit Gill ${ }^{*}, 1,2$, Rajendra Tibrewala ${ }^{3}$, Abram Poczter $^{3}$, Nahum Biger ${ }^{4}$, Harvinder S. Mand ${ }^{5}$, \\ Suraj P. Sharma ${ }^{6}$ and Karamjit S. Dhande ${ }^{2}$ \\ ${ }^{1}$ TUI University, Cypress, CA, USA \\ ${ }^{2}$ Fairleigh Dickinson University (Vancouver Campus), Vancouver, BC, Canada \\ ${ }^{3}$ School of Management, New York Institute of Technology, Old Westbury, NY 11568, USA \\ ${ }^{4}$ Academic Center Carmel, Shaar Palmer 4, Haifa, 33031, Israel \\ ${ }^{5}$ Sikh National College, Banga, Nawan Shahar, Punjab, India \\ ${ }^{6}$ GTB National College, Dakha, Ludhiana, Punjab, India
}

\begin{abstract}
This paper examines the effects of transformational leadership (TL) on student educational satisfaction (SES) and student stress (SS). Asian students enrolled in business management program at colleges and universities in British Columbia, Canada were surveyed to find out their perceptions as to whether TL used by faculty members improves SES and reduces SS. Results suggest that SES is positively related to the improvement in the level of perceived TL used by instructors/professors. The empirical findings of this paper also suggest that the reduction in the level of SS is related to the improvement in the level of perceived TL used by instructors/professors. However, TL does not mitigate the stress of graduate level students. This paper offers useful insights for instructors based on empirical evidence.
\end{abstract}

Keywords: Transformational leadership, student educational satisfaction, student stress, Asian students.

\section{INTRODUCTION}

The focus of this paper is to examine the effects of transformational leadership on student educational satisfaction and student stress.

Business motives have led Organization for Economic Cooperation and Development (OECD) countries to liberalize their policies to increase import and export in education, which in turn, increased number of international students in North American countries. The international market for educational services has to a large extent been demand-driven, particularly by students from the rapidly emerging countries of North and South-East Asia [1]. Most international trade in higher education services takes place within the OECD area, which received $85 \%$ of the world's foreign students [1]. Thus, foreign students represent an important source of export revenue for the North American Colleges and Universities particularly the United States of America and Canada.

Although, foreign students represent an important source of export revenue, they create some challenges for colleges and universities due to their different learning styles, behaviors, cultures, and attitudes, which in turn, lead to student leadership issues and challenges for instructors/ professors [2]. Consequently, international students tend to get dissatisfied with educational programs and get "stressed out" which lead to their withdrawal from the educational

*Address correspondence to this author at the TUI University, Cypress, CA, USA; E-mails: agill@tuiu.edu, agill@fdu.edu programs countering the educational export efforts of North American colleges/universities.

A disturbing trend in student health is the reported increase in student stress nationwide [3]. One of the stressors affecting students can be categorized as academic $[4,5]$. Academic stressors include the student's perception of the extensive knowledge base required and the perception of an inadequate time to develop it [6]. Students report experiencing academic stress at predictable times each semester with the greatest sources of academic stress resulting from taking and studying for exams, grade competition, and the large amount of content to master in a small amount of time [7-10]. Student retention and dropout rate often reflect an attempt to alleviate the stress that the student is experiencing [11].

Transformational leadership (TL) when employed by instructors/professors holds great promise for colleges and universities because they can be used to enhance student educational satisfaction (SES) and to reduce student stress (SS) resulting from education. Higher levels of SES and lower levels of SS improve student retention and thereby, increase education export revenue of the academic institutions.

The concept and definition of TL and the embodiment of that leadership in transformational leaders were first coined by Burns [12], and then extended and operationalized by Bass [13] as: "leadership and performance beyond expectations". 
Different authors [14-16] have found positive relationship between TL and employee job satisfaction; and negative relationship between TL and job stress [16-18]. However, there has been very little research testing the relationship between TL and SES and no research has been conducted to test the relationship between TL and SS. Nischan [19] found positive relationship between TL and SES in the education field. Therefore, it is important to examine the relationship between TL and SES and SS within an educational setting. The findings of said examination can be generalized to the broader educational field.

\section{TRANSFORMATIONAL LEADERSHIP AND STUDENT EDUCATIONAL SATISFACTION}

Similar to the importance of satisfying customers to retain them for profit-making institutions, satisfying matriculated students is equally important for student retention purposes [20]. Factors such as: i) faculty support to students, ii) quality of education, iii) faculty teaching styles, etc., have positive impact on student educational satisfaction [21-23].

Satisfaction with faculty support is very important for students in their decision to continue their studies at the same educational institution. Guolla [21] indicates that students consider themselves expert consumers of the education service experience since they have taken numerous courses previously. Building continuing study commitment is essential for retaining students in their current academic institution. Therefore, it is important to find strategies that can improve SES. TL, as one such strategy, has been found to encourage open communication with followers, which in turn, enhance SES. Within the educational field, Nischan [19] found a positive relationship to exist between TL and SES.

Students in general, and commerce students in particular, are subjected to face many education related issues such as an unclear mission, or weakly defined goals and objectives, due to poor leadership demonstrated by their instructors/professors in their study environments, all of which contribute to dissatisfaction with education. It has been found out that TL improves employee job satisfaction by increasing positive employee attitudes and clarifying the role of employees [14-16]. Therefore, it is theorized that students' educational satisfaction is related to the degree of their understanding of educational goals and objectives, which are the outcomes of TL. Hence, the following hypothesis is formulated:

H1: The more an instructor's leadership is perceived as being transformational, the higher will be the student's educational satisfaction.

\section{THE IMPACT OF TRANSFORMATIONAL LEADERSHIP ON STUDENT STRESS}

Stress, a mental and physical condition, affects students' effectiveness, personal health, and quality of home work. Stress is seen as the consequence of an inadequate fit of student needs and goals with the college environment [11]. Students are faced with many challenges such as heavy course loads, loneliness and conflict with roommates, etc. on a daily basis at colleges [24], which in turn, cause stress for students. When stress is perceived negatively or becomes excessive, students experience physical and psychological impairment [25], which has a negative impact on their academic performance. Therefore, the harmful and costly consequences of stress demonstrate the need for strategies to limit stressors within the organization [26]. TL, as one such strategy, has been found to encourage open communication with followers, which, in turn, reduces stress [17].

Although, students apply different methods such as effective time management, social support, positive reappraisal, engagement in leisure pursuits, etc., to reduce stress $[27,28]$, these methods are not enough. Authors such as Tracy and Hinkin [17], Gill et al. [18], etc. have found negative relationships between TL and stress in the service industry.

Students, in general, and commerce students, in particular, are subjected to the constant pressure of schoolwork, friends, instructors/professors, tests, quizzes, papers, and many times unplanned or unforeseen peaks in their study environments - all of which contribute to higher levels of study related stress. Therefore, it is theorized that students who are committed to their study mission, goals and objectives (TL outcomes) will feel less study stress than those who are less committed. Accordingly, the following hypothesis is formulated:

H2: The more an instructor's leadership is perceived as being transformational, the lower will be the student's stress.

\section{METHODS}

\section{Research Design}

This study utilized a survey research (a non-experimental field study design), appropriate to examine the research questions and test their derivative hypotheses. Gall et al. [29] also indicate that a survey research is a useful tool for studying sensitive opinions, attitudes, preferences, and behaviors of individuals, particularly when the opinions are reflections of larger underlying attitudinal constructs.

\section{Measurement and Variables}

In order to remain (for comparison and reference reasons) consistent with previous research, the measures were taken from three referent studies, which in turn were based on previous studies in marketing, education, and psychology. Measures pertaining to TL were taken from Dubinsky et al. [30] and Griffith [31], measures pertaining to SES were taken from Estaville et al. [32], and measures pertaining to SS were taken from Dubinsky et al. [30].

The questionnaire was pre-tested to ensure that it was effective in a pilot study conducted with 30 representative (of the full pool of respondents) students. Scale items were changed from five-point Likert scale to four-point Likert scale to have consistent responses and to receive possible valid responses from research participants. In addition, study program was used as a control variable.

Program was measured by a single item which asked respondents (Asian students) to indicate the program in which they were currently enrolled at a Canadian academic institution. Categorized alternative responses were: (i) B.S.B.A./B.Com., (0) M.B.A. 
Transformational Leadership (TL) was operationally defined as the extent to which instructors/professors motivate and encourage students to use their own judgment and intelligence to solve education related problems, transfer missions to students, and express appreciation for good work. Dubinsky et al. [30] used the twelve-item tolerance-of-freedom scale [33], which measures a sales person's relationship with their managers and Griffith [31] used four items that measured intellectual stimulation of teachers. Based on Dubinsky et al.'s [30] and Griffith's [31] CFA (confirmatory factor analysis), two items from each study were selected to measure the "transformational leadership" variable in this study. Scale items were reworded to apply to students in the education field and the reliability of these re-worded items was re-tested. These items are:

To what extent does your instructor/professor...?

TL1) ... make you proud to be associated with him or her?

TL2) ... encourage you to study?

TL3) ... transmit a "sense of mission" to you?

TL4) ... let you use your intelligence to overcome obstacles in the classroom and outside the classroom?

Respondents were asked to indicate their agreement with each item using a four-point Likert scale ranging from "None" to "Extreme". Higher scores indicate that students have a closer relationship with their instructors/professors.

Griffith [31] reported Cronbach alpha of 0.89 for the above 2 items. Cronbach alpha was not reported by Dubinsky et al. [30] for the above 2 items. We calculated a Cronbach alpha of .80 on the responses of the 30 students who participated in the pre-test of this scale. Based on the scales reliability, we included all four items in our final questionnaire.

Student Educational Satisfaction (SES) was operationalized as the extent to which students were satisfied with: i) the help they receive from their instructor/professor to understand course materials, ii) the instructor's/professor's teaching style, and iii) education quality provided by their instructor/professor. Estaville et al. [32] used fifteen items to measure student's general satisfaction of their educational department, from which we selected three specific items to measure directly the "student educational satisfaction" variable. Scale items were reworded to apply to students in the education field and the reliability of these re-worded items was re-tested. These items are:

To what extent are you satisfied with ...?

SES1) ... the help that you received from your instructors/professors?

SES2) ... the teaching styles of your instructors/professors?

SES3) ... the overall quality of education provided by your instructors/professors?

Respondents were asked to indicate their agreement with each item, using a four-point Likert scale ranging from "None" to "Extreme". Higher scores reflect higher level of student educational satisfaction.

Cronbach alpha was not reported by Estaville et al. [32] for the above 3 items. We calculated a Cronbach alpha of .90 on the responses of the 30 students who participated in the pre-test of this scale. Based on the scales' reliability, we included all three items in our final questionnaire.

Student Stress (SS) was operationally defined as the extent to which students feel a tension or anxiety caused by their studies. Dubinsky et al. [30] used the two stress items developed by Motowidlo et al. [34]. Based on the CFA reported by Dubinsky et al. [30], both items were selected to measure the "student stress" variable. Scale items were reworded to apply to students in the education field and the reliability of these re-worded items was re-tested. These items are:

To what extent do you feel...?

SS1) ...tense because of your study?

SS2) ...nervous because of your study?

Respondents were asked to indicate their agreement with each item, using a four-point Likert scale ranging from "None" to "Extreme". Higher scores reflect a higher level of stress perceived by the students.

Cronbach alpha was not reported by Dubinsky et al. [30] for the above 2 items. We calculated a Cronbach alpha of .79 on the responses of the 30 students who participated in the pre-test of this scale. Based on the scales reliability, we included both items in our final questionnaire.

\section{Sampling Frame, Questionnaire Distribution, and Collection}

The study's pool of subjects includes only (to avoid sampling frame issues) Asian students attending colleges and universities in the Lower Mainland area of British Columbia, Canada (Vancouver, Burnaby, New Westminster, Surrey, and Richmond).

\section{Sampling Methods and Issues}

A list of all academic institutions (colleges and universities) in the Lower Mainland area of British Columbia, Canada was created, from which a mailing list was compiled of faculty and students, and to which survey questionnaires were distributed. As the academic institutions were reluctant to provide us with their full student rosters, we need define this subject recruitment method as a convenience (non-random) sampling method.

To mitigate possible sampling bias (the threat to representational ability of a sample), we guided our data collecting team to ensure that subjects met inclusion criteria: i) country of origin (South East Asia), and ii) study program (undergraduate and graduate).

From our sample population pool of about 800 student subjects who met all inclusion criteria, 204 fully completed survey questionnaires (a response rate of $25.50 \%$ ), were gathered in-person by our data collecting team, and by post.

The confidentiality of all subjects was assured by having them respond anonymously to the questionnaires. All subjects of the study participated voluntarily.

\section{ANALYSES AND RESULTS}

\section{Data Analysis Methods}

Measures of central tendency, variance, skewness, and kurtosis were calculated on the responses to all of the items. 
Table 1. Student Data Statistics

\begin{tabular}{|c|c|c|}
\hline & \multicolumn{2}{|c|}{$\mathbf{N}=\mathbf{2 0 4}$} \\
\hline & $\overline{\mathbf{x}}$ & $\sigma$ \\
\hline \multicolumn{3}{|l|}{ To what Extent do your Instructors/Professors ....? } \\
\hline TL1) ....make you proud to be associated with them? & 2.91 & 0.840 \\
\hline TL2) ....encourage you to study? & 3.05 & 0.748 \\
\hline TL3) ....transmit a "sense of mission" to you? & 2.93 & 0.828 \\
\hline TL4) ....let you use your intelligence to overcome obstacles in the classroom and outside the classroom? & 2.93 & 0.822 \\
\hline \multicolumn{3}{|l|}{ To what Extent are you Satisfied with ....? } \\
\hline SES1) ....the help that you receive from your Instructors/Professors? & 2.87 & 0.784 \\
\hline SES2) ....teaching styles of your Instructors/Professors? & 2.93 & 0.791 \\
\hline SES3) ....the quality of education provided by your Instructors/Professors? & 2.88 & 0.792 \\
\hline \multicolumn{3}{|l|}{ To what Extent you Feel ....? } \\
\hline SS1) ....tense because of your study? & 2.30 & 1.020 \\
\hline SS2) ....nervous because of your study? & 2.20 & 1.022 \\
\hline
\end{tabular}

Skewness measures for all of the items were within the range of -1.0 to +1.0 , which is considered to be an excellent range for most research that requires using statistics appropriate to normal distributions. Therefore, statistics that assume scalar values and symmetric distributions were used to test the hypotheses. Table 1 shows student data statistics.

The $\mathrm{n}=204$ student subjects break up into the following groups:

- $\quad$ Country of origin: i) China $=161(78.92 \%)$, ii) India $=33(16.18 \%)$, iii) Taiwan $=5(2.45 \%)$, and iv) Korea $=5(2.45 \%)$.

- $\quad$ Program: i) Undergraduate $=95$ (46.57\%), and ii) MBA $=109$ (53.43).

Table 3. Rotated Component Matrix
Table 2. Total Variance Explained - Rotation Sums of Square Loadings

\begin{tabular}{|c|c|c|c|}
\hline \multirow{2}{*}{ Component } & \multicolumn{3}{|c|}{ Total Variance Explained } \\
\cline { 2 - 4 } & \multicolumn{3}{|c|}{ Rotation Sums of Squared Loadings } \\
\cline { 2 - 4 } & Total & \% of Variance & Cumulative \% \\
\hline \hline 1 & 3.333 & 37.029 & 37.029 \\
\hline 2 & 2.617 & 29.081 & 66.111 \\
\hline 3 & 1.875 & 20.838 & 86.949 \\
\hline
\end{tabular}

Extraction Method: Principal Component Analysis.

\begin{tabular}{|c|c|c|c|}
\hline & \multicolumn{3}{|c|}{ Component } \\
\hline \multicolumn{4}{|l|}{ To what Extent do your Instructors/Professors ....? } \\
\hline TL1) ....make you proud to be associated with them? & 0.829 & 0.369 & -0.111 \\
\hline TL2) ....encourage you to study? & 0.850 & 0.365 & -0.091 \\
\hline \multicolumn{4}{|l|}{ To what Extent are you Satisfied with ....? } \\
\hline SES1) ....the help that you receive from your Instructors/Professors? & 0.397 & 0.809 & -0.105 \\
\hline SES2) ....teaching styles of your Instructors/Professors? & 0.348 & 0.872 & -0.059 \\
\hline SES3) ....the quality of education provided by your Instructors/Professors? & 0.448 & 0.825 & -0.021 \\
\hline SS2) ....nervous because of your study? & -0.106 & -0.040 & 0.954 \\
\hline
\end{tabular}


Using principle component rotation and Varimax rotation, a Confirmatory Factor Analysis (CFA) on the nine items was run. Three factors explained $86.95 \%$ of the variance in the nine items (see Table 2), and all of the items loaded on the expected factors (see Table 3 ).

The four "transformational leadership" items were factor analyzed, and the resultant weighted score was used as the "TL" scale. The four items loaded roughly equally on the scale, and explained $84.67 \%$ of the variance. Cronbach alpha calculated was 0.939 on the four items.

The three "student educational satisfaction" items were factor analyzed, and the resultant weighted score was used as the "SES" scale. The three items loaded roughly equally on the scale, and explained $86.04 \%$ of the variance. Cronbach alpha calculated was 0.919 on the three items.

The two "student stress" items were factor analyzed, and the resultant weighted score was used as the "SS" scale. The two items loaded roughly equally on the scale, and explained $92.25 \%$ of the variance. Cronbach alpha calculated was 0.916 on the two items.

\section{TESTING OF HYPOTHESES}

It was hypothesized that:

i) The more an instructor's leadership is perceived as being transformational, the higher will be the student's educational satisfaction, and

ii) The more an instructor's leadership is perceived as being transformational, the lower will be the student's stress.

A positive relationship between TL and SES was found (see Table 4). That is, the degree of perceived educational satisfaction of Asian students is the function of TL used by their instructors/professors.

A negative relationship between TL and SS was found (see Table 4). That is, the reduction in the degree of perceived stress of Asian students is related to the improvement in the degree of perceived TL used by their instructors/professors.

No significant relationships between i) Program and SES and ii) Program and SS were found (see Table 4).

The regression equations are as follows:

$\mathrm{SES}=-0.029+0.747 \mathrm{TL}+0.062$ Program

$\mathrm{SS}=0.101-0.227 \mathrm{TL}-0.216$ Program

SES (Undergraduate Program) $=0.036+0.701 \mathrm{TL}$

SS (Undergraduate Program) $=-0.101-0.430 \mathrm{TL}$

SES (Graduate Program) $=-0.025+0.806 \mathrm{TL}$

SS $($ Graduate Program $)=0.117+0.038 \mathrm{TL}$

The sample size based on the study program breaks up into the following groups:

i) Undergraduate $=95(46.57 \%)$, and

ii) $\quad$ Graduate $=109(53.43)$.

We noted that the size of the sample (with a predominance of graduate level students), might affect the results. We first tested to see if TL, SES, and SS were significantly different between undergraduate and graduate students. Using one-way ANOVAs, we found that perceived TL did NOT differ between the 2 types of students (sig. = 0.347), perceived SES did NOT differ between the 2 types of students $($ sig. $=0.253$ ), and perceived SS did NOT differ between the 2 types of students (sig. $=0.080$ ).

We then re-tested the hypotheses for subsets of the sample.

\section{Undergraduate Students}

A positive relationship between TL and SES was found (see Table 4). That is, the degree of perceived educational satisfaction of undergraduate level Asian students is the function of TL used by their instructors/professors.

A negative relationship between TL and SS was found (see Table 4). That is, the reduction in the degree of perceived stress of undergraduate level Asian students is related to the improvement in the degree of perceived TL used by their instructors/professors.

\section{Graduate Students}

A positive relationship between TL and SES was found (see Table 4). That is, the degree of perceived educational satisfaction of graduate level Asian students is the function of TL used by their instructors/professors.

No significant relationships between TL and SS were found (see Table 4).

Tables 5 and $\mathbf{6}$ provide the summary statistics of the regression analysis.

Note that around:

- $\quad 56.2 \%\left(\mathrm{R}^{2}=0.562\right)$ of the variance in the degree of SES can be explained by the degree of Program and TL,

- $6.60 \%\left(\mathrm{R}^{2}=0.066\right)$ of the variance in the degree of SS can be explained by the degree of Program and TL,

- $\quad 54.20 \%\left(\mathrm{R}^{2}=0.542\right)$ of the variance in the degree of SES can be explained by TL in the undergraduate program,

- $\quad 22.60 \%\left(\mathrm{R}^{2}=0.226\right)$ of the variance in the degree of SS can be explained by the degree of TL in the undergraduate program,

- $\quad 58.20 \%\left(\mathrm{R}^{2}=0.582\right)$ of the variance in the degree of SES can be explained by TL in the graduate program, and

- $\quad 0.10 \%\left(\mathrm{R}^{2}=0.001\right)$ of the variance in the degree of SS can be explained by the degree of TL in the graduate program.

As shown in Table 6, ANOVA's tests (except for the relationship between TL and SS - Graduate Program) are also significant.

\section{DISCUSSION}

The main purpose of this study was to examine whether SES and stress levels are related to the degree of TL used by instructors/professors. These students' perceptions and judgments are the basis of our findings that the degree of perceived SES and SS are related to the degree of TL used by instructors/professors at the educational institutions. This 
Table 4. Regression Coefficients ${ }^{\text {a, }}$,

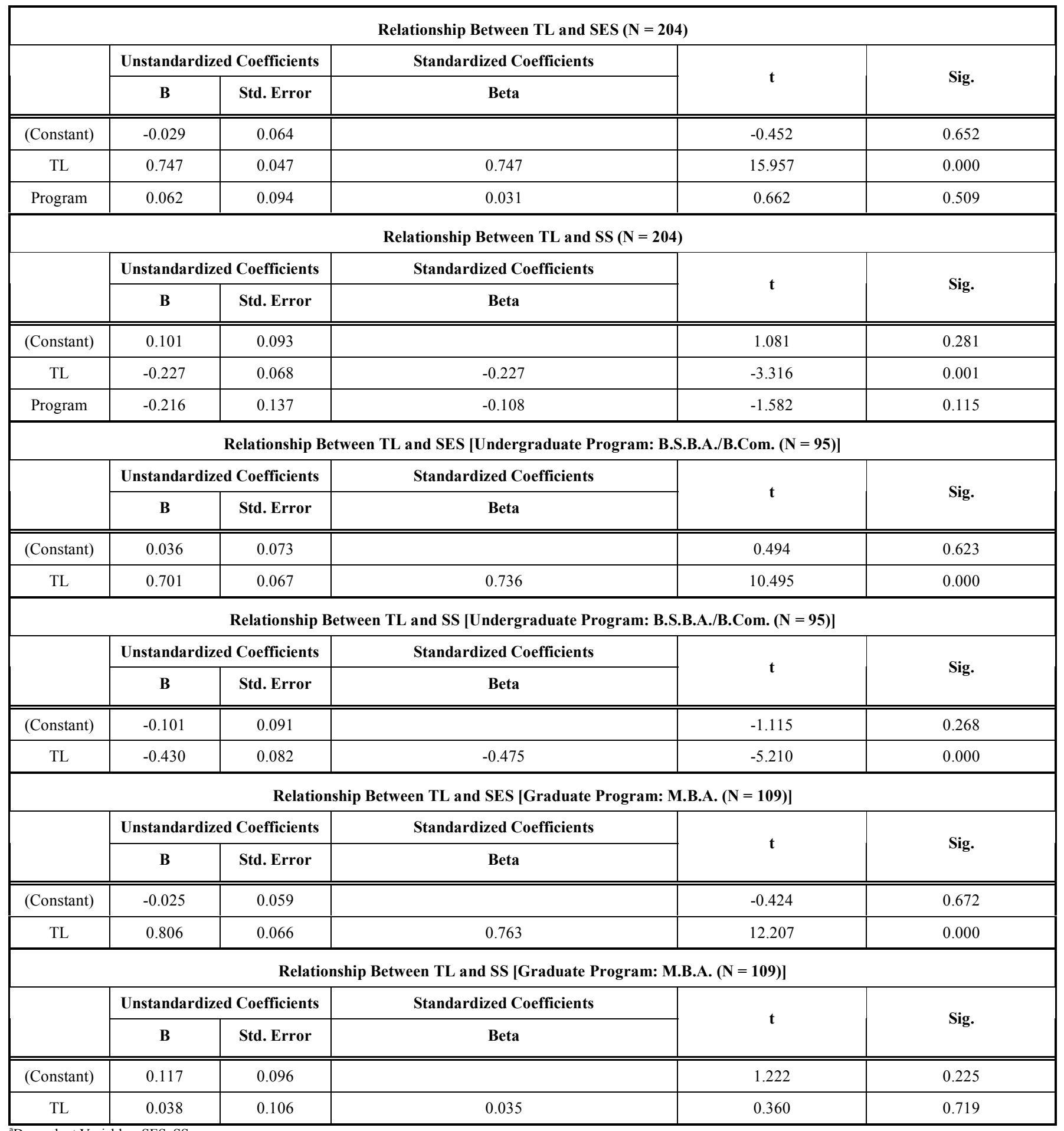

${ }^{a}$ Dependent Variables: SES, SS.

bIndependent Variables: TL and Program. Program was dealt with as a single dummy variable: i) B.S.B.A./B.Com., 0) M.B.A.

${ }^{c}$ Linear Regression through the Origin.

$\mathbf{N}=$ Number of responses.

$\mathbf{T L}=$ Transformational Leadership.

SES $=$ Student Educational Satisfaction

SS $=$ Student Stress .

lends the support to the finding of previous authors [14-16] who found positive relationship between TL and employee job satisfaction; and [16-18] who found negative relationship between TL and employee job stress.
The empirical findings of this paper also suggest that degree of perceived satisfaction of undergraduate and graduate level students is related to the degree of TL used by instructors/professors at the educational institutions. Although results suggest that the perceived stress of 
Table 5. Model Summary

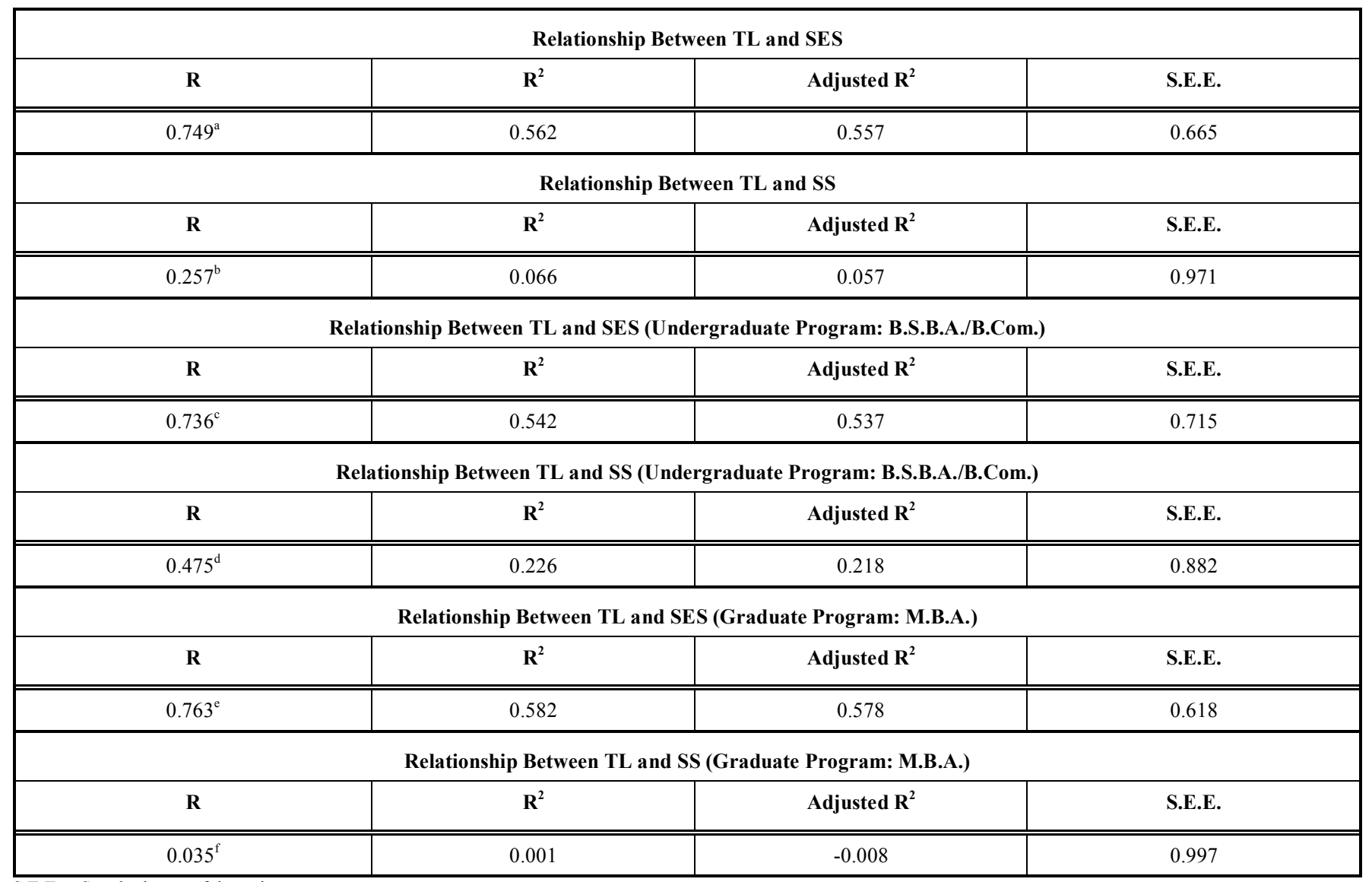

S.E.E. $=$ Standard error of the estimate

${ }^{a}$ Predictors (Relationship between TL and SES): (Constant), Program, TL.

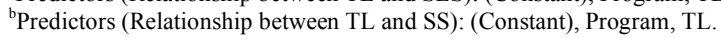

'Predictors (Relationship between TL and SES - Undergraduate Program): (Constant), TL.

${ }^{\mathrm{d} P r e d i c t o r s}$ (Relationship between TL and SS - Undergraduate Program): (Constant), TL.

${ }^{\mathrm{e} P r e d i c t o r s}$ (Relationship between TL and SES - Graduate Program): (Constant), TL.

fPredictors (Relationship between TL and SS - Graduate Program): (Constant), TL.

undergraduate level students is negatively related to the improvement in the level of perceived TL used by their instructors/professors, no significant relationship between $\mathrm{TL}$ and the stress of graduate level students $\left(\mathrm{R}^{2}=0.226, \mathrm{R}^{2}=\right.$ 0.001 , respectively) was found. It can be concluded that the maturity of the students does not really matter when it comes to the effect of TL on their perceived level of stress. The differences in R-Squares $\left(\mathrm{R}^{2}\right)$ for undergraduate and graduate level students may be because TL is new to the undergraduate level students and graduate level students expect their instructors/professors to use TL anyway. Therefore TL does not impact on the perceived level of stress of graduate level students.

Students play a boundary-spanning role where they interact with many individuals from inside (fellow students, administrative staff, and instructors/professors) and outside (employers) their college/university. This large role set requires students to satisfy frequently variegated needs and expectations of multiple parties (only one of which is their instructor/professor), which leads to student stress and dissatisfaction with education. Student stress and dissatisfaction with education leads to high student turnover which is not in the favor of educational institutions. Therefore, it is important for North American colleges/uni- versities to increase SES and to reduce SS, which in turn, improves student retention of Asian students.

\section{IMPLEMENTING TRANSFORMATIONAL LEADER- SHIP BEHAVIORS}

Although TL enhance students' educational satisfaction and reduces student stress, there are some barriers that can make it difficult to implement TL approaches (e.g., lack of student's understanding of the course goals and objectives, communication barriers, lack of time, cultural barriers, instructors' understanding the degree to which transformational leadership needs to be implemented, etc.) [35].

To overcome with above challenges, instructors need to communicate the course goals and objectives to students by "breaking-them-down" for each individual student. They should foster upward as well as downward communication. Practicing effective listening skills (e.g., showing students that you want to listen, being patient, holding your temper, going easy on argument and criticism, and asking relevant questions) can go a long way toward demonstrating respect and concern for students' personal feelings as well as overcoming communication and cultural barriers. Ultimately, instructors/professors should act as mentors (e.g., educate, advise, coach, support, and encourage) to students 
Table 6. ANOVA

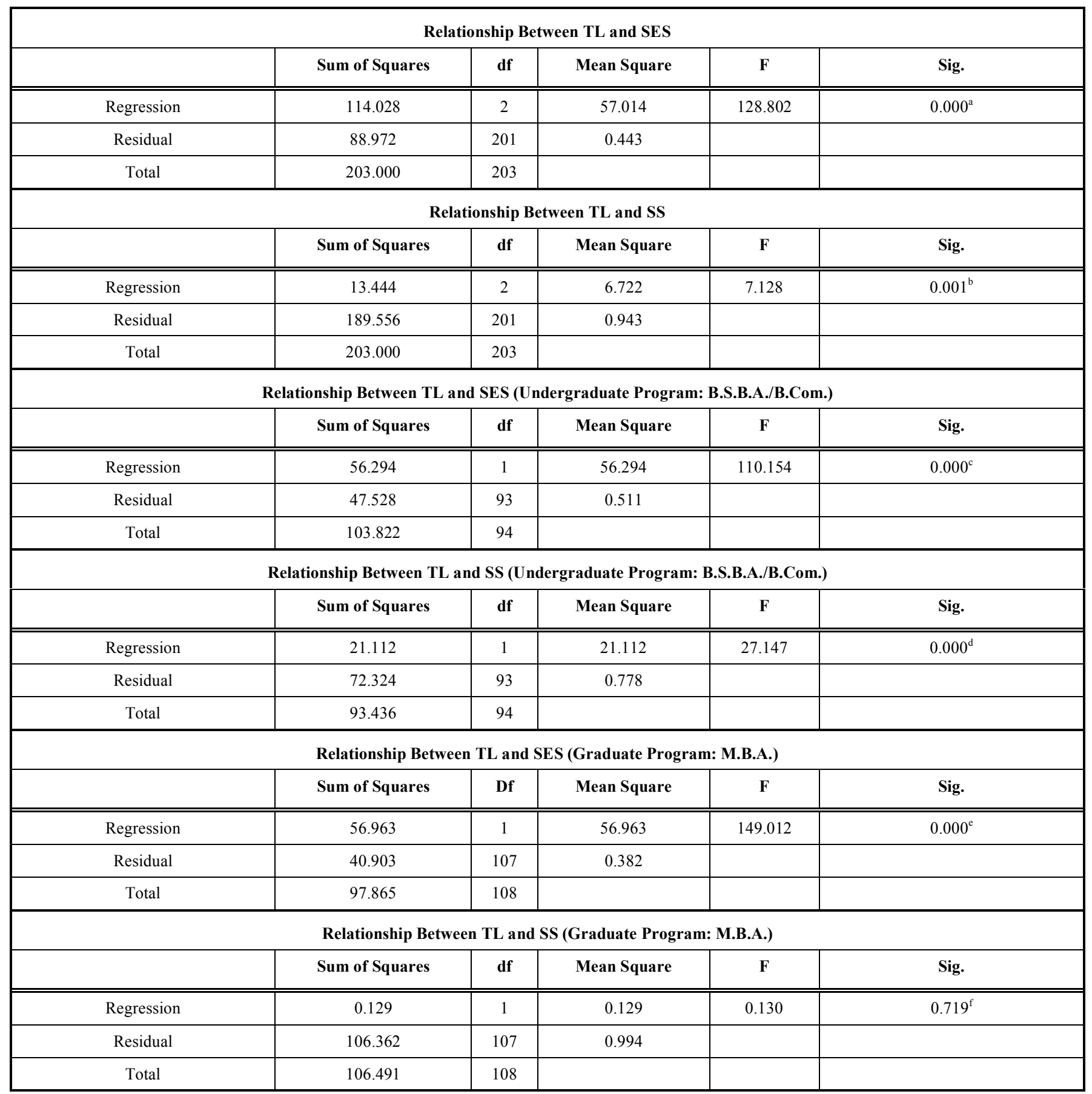

${ }^{a}$ Predictors (Relationship between TL and SES): (Constant), Program, TL,

${ }^{\mathrm{b}}$ Predictors (Relationship between TL and SS): (Constant), Program, TL.

'Predictors (Relationship between TL and SES - Undergraduate Program): (Constant), TL.

${ }^{\mathrm{d}}$ Predictors (Relationship between TL and SS - Undergraduate Program): (Constant), TL.

${ }^{\mathrm{e}}$ Predictors (Relationship between TL and SES - Graduate Program): (Constant), TL.

${ }^{\mathrm{f}}$ Predictors (Relationship between TL and SS - Graduate Program): (Constant), TL.

to fully overcome "the degree to which TL needs to be implemented" barriers [35].

All of the above require instructors/professors to internalize the importance of showing genuine concern and respect for students and their learning styles. In practice, although it may be difficult for some instructors/professors to increase their use of these TL behaviors and some students may eye a change in teaching styles with skepticism, the potential benefits far outweigh the costs, and such behaviors are develop-able. The importance of such a leadership development process, however, must be championed and strongly supported by senior leadership (e.g., the dean) [35].

\section{PRACTICAL IMPLICATIONS}

If Asian students perceive that their instructors/professors are using high level TL, SES is perceived as higher level 
than if it is perceived as being used at lower level. If Asian students perceive that their instructors/professors are using high level TL, SS is perceived as lower level than if it is perceived as being used at lower level.

\section{RECOMMENDATIONS FOR FUTURE RESEARCH}

Although this study clearly shows that SES and decreased SS are the functions of TL, we have not covered all possible factors explaining/predicting SES and SS. The possible additional variables that should be researched in the future research study include:

- $\quad$ The degree to which instructors/professors understand the consequences of using TL and their desire to use it,

- $\quad$ The degree to which instructors/professors understand the desire of their students to accept TL,

- The degree to which students desire to accept TL from their instructors/professors,

- $\quad$ The degree to which instructors/professors understand the SES, and

- $\quad$ The degree to which instructors/professors understand the SS.

Furthermore, as discussed above, a more in-depth look at foreign students' maturity, possible preparation for academic studies, and their personal expectations from their studies may provide additional insight as to their perceptions of satisfaction and stress levels.

\section{REFERENCES}

[1] Larsen K, Vincent-Lancrin S. The learning business: can trade in international education work. Org Econ Cooperat Dev 2006; 235: 26-9.

[2] Salvarajah C. Cross-cultural study of Asian and European student perception; the need to understand the changing educational environment in New Zealand. Cross Cult Manag 2006; 13: 142-50.

[3] Sax LJ. Health trends among college freshmen. J Am Coll Health 1997; 45: 252-62.

[4] Goodman ED. How to handle the stress of being a student. Imprint 1993; 40: 43-7.

[5] LeRoy A. How to survive a nontraditional nursing student. Imprint 1988; 35: 73-86.

[6] Carveth JA, Gesse T, Moss N. Survival strategies for nursemidwifery students. J Nurse Midwifery 1996; 41: 50-4.

[7] Abouserie R. Sources and levels of stress in relation to locus of control and self esteem in university students. Educ Psychol 1994; 14: 323-30.

[8] Archer J, Lamnin A. An investigation of personal and academic stressors in college campuses. J Coll Stud Personnel 1985; 26: 21015.

[9] Britton BK, Tesser A. Effects of time management practices on college grades. J Educ Psychol 1991; 83: 405-10.

[10] Kohn JP, Frazer GH. An academic stress scale: identification and rated importance of academic stressors. Psychol Rep 1986; 59: 415-26.

[11] Seifrid JM. An analysis of leadership style and life stressors on marital satisfaction among conservative evangelical seminary students. The Southern Baptist Theological Seminary, AAT 2003.
[12] Burns JM. Leadership. New York: Harper and Row 1978.

[13] Bass BM. Leadership and performance beyond expectations. New York: Free Press 1985.

[14] Niehoff BP, Enz CA, Growver RA. The impact of top-management actions on employee attitudes and perception. Group Org Stud 1990; 15: 337-53.

[15] Berson Y, Linton J D. An examination of the relationships between leadership style, quality, and employee satisfaction in $R \& D$ versus administrative environments. J R D Manag 2005; 35: 51-61.

[16] Dubinsky AJ. A research odyssey in sales management. Acad Market Sci Rev 1998; 1998: 1.

[17] Tracy JB, Hinkin TR. Transformational leaders in the hospitality industry. J Cornell Hotel Restaur Admin Q 1994; 35: 18-24.

[18] Gill A, Flaschner AB, Shachar M. Mitigating stress and burnout by implementing transformational-leadership. Int $\mathrm{J}$ Contemp Hosp Manage 2006; 18: 469-81.

[19] Nischan TP. Transformational leadership as a predictor of effectiveness, extra effort, and satisfaction in a community college classroom environment. Nova Southern University, 1997; 156 pages, AAT 9735927.

[20] DeShields Jr. OW, Kara A, Kaynak E. Determinants of business student satisfaction and retention in higher education: applying Herzberg's two-factor theory. Int J Educ Manag 2005; 19: 128-40.

[21] Guolla M. Assessing the teaching quality to student satisfaction relationship: Applied customer satisfaction research in the classroom. J Market Theor Pract 1999; 7: 87-98.

[22] Umbach PD, Porter SR. How do academic departments impact student satisfaction? Understanding the contextual effects of departments. Res High Educ 2002; 43: 209-34.

[23] Poirier D. The field-dependence/field-independence dimensions of cognitive style as a correlate of success in post-secondary business and industrial arts programs. Columbia: University of Missouri 1980; .97 pages, AAT 8202686 .

[24] Marcus D. Long Island college freshmen find ways to adjust. Washington: Tribune Business News 2008.

[25] Murphy MC, Archer J. Stressors on the college campus: A comparison of 1985-1993. J Coll Stud Devel 1996; 37: 20-8.

[26] Savery LK, Luks JA. The relationship between empowerment, job satisfaction, and reported stress levels: some Australian evidence. Leadership Organ Devel J 2001; 22: 97-105.

[27] Blake RL, Vandiver TA. The association of health with stressful life changes, social supports, and coping. Fam Pract Res J 1988; 7 : 205-18.

[28] Mattlin JA, Wethington E, Kessler RC. Situational determinants of coping and coping effectiveness. J Health Soc Behav 1990; 31: 103-22.

[29] Gall M, Borg W, Gall J. Educational research: an introduction $6^{\text {th }}$ ed. White Plains, NY: Longman Publishing 1996.

[30] Dubinsky AJ, Yammarino FJ, Jolson MA, Spangler WD. Transformational leadership: an initial investigation in sales context". J Person Selling Sales Manag 1995; 15: 15-31.

[31] Griffith J. Relation of principal transformational leadership to school staff job satisfaction, staff turnover, and school performance. J Educ Admin 2004; 42: 333-56.

[32] Estaville LE, Brown BJ, Caldwell S. "Geography undergraduate program essentials: retention”. J Geogr 2006; 105: 47-53.

[33] Bass BM, Avaolio BJ. Manual: the multifactor leadership questionnaire. Palo Alto, CA: Consulting Psychologists Press 1989.

[34] Motowidlo SJ, Packard JS, Manning MR. Occupational stress: its causes and consequences for job performance. J Psychol 1986; 71: 618-29.

[35] Gill A, Biger N, Pai C, Tibrewala R, Nagpal V. Factors that affect commitment to continue studies among business students: a comparative study of Asian and Canadian students studying in Canada. Open Educ J 2009; 2: 25-33. 